\title{
Determination of temporal changes in land uses in Hasanlar Dam basin
}

\section{Hasanlar baraj havzasında arazi kullanımındaki zamansal değişimlerin belirlenmesi}

\author{
Hayati Zengin ${ }^{1}$ D, Hakan Yasin Özdemir ${ }^{2}$ (D), Ahmet Salih Değermenci' (DD \\ 'Department of Forest Management and Planning, Düzce University, Faculty of Forestry, Düzce, Turkey \\ ${ }^{2}$ Düzce Forest Enterprise, Düzce, Turkey
}

\section{Cite this paper as:}

Zengin, H., Özdemir, H.Y.,

Değermenci, A.S., 2018.

Determination of temporal changes in land uses in Hasanlar Dam basin.

Forestist 68(1): 53-60

\section{Address for Correspondence:}

Hayati Zengin

e-mail:

hayatizengin@duzce.edu.tr

Received Date:

13.02.2017

Accepted Date:

28.10.2017

\begin{abstract}
The impact of human activities on nature is increasing day by day along with changing patterns of land use. These changes also influence the level of the expected function of natural ecosystems. Therefore, for the purposes of meeting the needs of a growing population for ecosystem services at optimal levels, it is important to understand and control the factors that affect land use and to control the changes in land use according to the objectives. The aims of this study were to determine land-use patterns in Hasanlar Dam basin per period, analyze the temporal changes in land use according to area, and determine the reasons for the changes in the basin by digitizing the maps of the basin area belonging to the period between 1986 and 2010. Forest land-use patterns were categorized into the following six groups: forest, (deciduous, coniferous, mixed, and degraded), forest gaps, hazelnut, agriculture, pasture, and other areas. The forest area that was 64,843 ha in 1986 had declined to 62,709 ha in 2010 . Hazelnut areas covering an area of 3,636 ha in 1986 were represented as agricultural areas in the 2010 stand maps. The agricultural areas that were 8,925 ha in 1986 increased to 15,420 ha in 2010 . The pasture areas comprising 267 ha in 1986 decreased to 19 ha in 2010. Other areas decreased from 1,302 ha to 825 ha between 1986 and 2010. Through the Melen project, water is being transported to İstanbul from Hasanlar Dam. Therefore, since changes in the land-use pattern in the Hasanlar Dam basin may affect both water efficiency hydrologically and the quality of water, it is necessary to monitor the changes in forest, agriculture, pasture, forest soil, and other areas and also the changes in the demographic structure. In addition, it must be ensured that these changes cause the minimum impact on water yield and quality.
\end{abstract}

Keywords: Land-use changes, GIS, Hasanlar dam basin, temporal changes

\section{ÖZ}

Insanların doğa üzerindeki etkileri gün geçtikçe artmakta ve arazi kullanım biçimleri değişmektedir. Bu değişimler, doğal ekosistemlerden beklenen fonksiyonların düzeyini de etkilemektedir. Bu nedenle artan nüfusun ekosistem hizmetlerine yönelik gereksinimlerinin optimal düzeyde karşlanabilmesi için arazi kullanımında etkili faktörlerin anlaşılması ve değişimlerin amaçlar doğrultusunda kontrol edilmesi önemlidir. Bu çalışmada, Hasanlar baraj havzasının 1986-2010 yıllarına ait meşcere haritaları, bilgisayar ortamında sayısallaştırıarak, dönemler itibariyle arazi kullanım biçimleri belirlenmeye, arazi kullanımındaki zamansal değişimler alansal olarak hesaplanmaya ve değişimin sebepleri belirlenmeye çalışılmıştır. Arazi kullanım biçimleri orman (yapraklı, ibreli, karışık, bozuk), orman toprağı, fındıklık, ziraat, mera ve diğer alanlar olmak üzere 6 gruba ayrılmıştır. Orman alanları 1986'da 64843 ha iken 2010 yılında 62709 ha'a gerilemiş̧tir. Fındık alanları 1986'da 3 636 ha'ık bir alana sahipken 2010 yılı meşcere haritalarında ziraat alanları içerisinde gösterilmiştir ve 1986 yılında 8925 ha olan ziraat alanları 2010 yılında 15420 ha'a yükselmiştir. Mera alanları 1986'da 267 ha iken 2010'da 19 ha'a gerilemiştir. Diğer alanlar 1986-2010 yılları arasında 1302 ha'dan 2010'da 825 ha'a gerilemiştir. Melen projesi ile Hasanlar barajından Istanbul'a su taşınmaktadır. Dolayısı ile Hasanlar barajı havzasındaki arazi kullanımının değişmesi hidrolojik olarak hem su verimini hem de su kalitesini etkileyebileceğinden orman, ziraat, mera, orman toprağı, diğer alanlar ve demografik yapıdaki değişimlerin izlenmesi, su verimi ve kalitesinin bu değişimlerden en az şekilde etkilenmesinin sağlanması gerekmektedir.

Anahtar Kelimeler: Arazi kullanım değişimi, CBS, Hasanlar baraj havzası, zamansal değişim 


\section{INTRODUCTION}

There has been a constant change in the spatial and structural characteristics of forests and forest stands, which form the forests, due to natural events and also technical interventions. Structural changes in turn lead to various land-use changes, which may end up with deforestation. Local changes occurring at the stand level can cause problems in the functioning of the entire forest ecosystems and prevent the realization of the expected operations. Throughout history, people have fulfilled several of their requirements from forests. Issues such as the sustainability of the forest were not a concern when the population density was low compared to that present today. However, due to the growing pressure on forest resources, issues such as ensuring the continuity of these sources has begun to gain importance. In this context, several initiatives and applications are available at both national and international levels for ensuring the sustainability of forest resources. In the United Nations Sustainable Forest Management Declaration (1992), emphasis was made on the necessity of sustainable use of forest resources on a global level (OGM, 2013).

The improper use of land and natural resources can cause several environmental problems such as floods and landslides, which are caused by factors such as soil compaction and deforestation. These problems also occur in the form of destruction of natural habitats as a consequence of climate change, loss of biodiversity, and pollution of water, air, and soil (European Environment Agency, 2010). In a world where natural resources are limited but the human need is unlimited, to ensure sustainable use, temporal changes in land use should be determined and lands should be used according to the land-use plans prepared by experts (Özçağlar et al. 2006). The geographic information system (GIS), in which analysis and examination are based on computational foundation, can be used in the studies conducted to achieve healthy results successfully and in a short time. In this context, the analysis and examination of the relationship between natural resources and existing land use is of paramount importance for future physical-civic planning approaches (Gülersoy, 2014).

There is extensive research addressing the land-use changes at both local and global levels. It has been estimated that for maintaining the existing land-use pattern in the European Union countries, agricultural land would be reduced gradually until the year 2080, which would also not meet the needs of the growing population (Rounsevell et al. 2005). Based on studies that have examined the effects of land use on soil and water resources, it has been observed that traditional land use has been abandoned and new methods of land use have resulted in land degradation and loss of biodiversity (Wu and Tiessen, 2002). In some of the recent studies conducted in Turkey, land-use changes were examined by Gülersoy $(2013,2014)$ in Manisa and Çorum Central Districts and by Somuncu et al. (2010) in the plateaus of Gümüşhane Province using various remote sensing methods. Özşahin and Atasoy (2014) evaluated land-use changes and soil characteristics of the lower parts of the Asi River. Erol (2007) addressed land use in Turkey through the basin approach. Kadıogulları and Karahalil (2013) analyzed the temporal and spatial variations of the quantity of carbon in Köprülü Kanyon National Park. Değermenci and Zengin (2016) evaluated the spatial and temporal variations of the Daday planning unit along with carbon stock status and demonstrated the spatial and temporal variations in carbon accumulation. Studies conducted in Turkey have dealt with land-use changes in association with population, soil, erosion, water efficiency, and carbon variations. Forest cover in Turkey has increased steadily in terms of area in the last 30-40 years (OGM, 2015). However, this must not be considered as a uniform increase in every part of Turkey. The form of land-use changes between regions and countries and the land-use patterns vary in different regions even within the same country. Understanding the layout of land-use changes, the causes, and the possible consequences will help in identifying solutions in advance to the various problems that may arise in the future and will also help in improving the overall strategy (Bussink and Hijmans, 2000). In this context, knowledge of the related factors that affect land-use changes would provide invaluable information in terms of land-use planning and sustainable management of resources.

Therefore, the aim of this study was to determine the changes in land-use patterns and their causes in the Hasanlar Dam basin located on the Melen River within the boundaries of Bolu Regional Directorate of Forestry. For this purpose, changes in land-use patterns that have occurred between 1986 and 2010 in the dam basin, which consists of 11 forest chiefdoms (FCs), were spatially evaluated.

\section{MATERIALS AND METHODS}

\section{General Characteristics of the Study Area}

The study area consists of the Hasanlar Dam basin located in Düzce Province; the primary settlement in this area is the Yığılca town. In addition, within the study area, there are 50 villages that are connected to Yığılca, Kaynaşlı, and Düzce Province. The size of the study area is $78,973 \mathrm{ha}$, and it is located at $40^{\circ} 47^{\prime} 06^{\prime \prime}$ to $41^{\circ}$ $02^{\prime} 02^{\prime \prime}$ north latitude and $31^{\circ} 24^{\prime} 03^{\prime \prime}$ to $31^{\circ} 40^{\prime} 45^{\prime \prime}$ east longitude. The average elevation above the sea level is $937 \mathrm{~m}$ (Figure 1).

The agricultural areas of Yığllca, which has a rough and sloppy terrain, are inadequate generally covered with forest areas (Anonymous, 2014). The majority of forests are composed of pure and mixed stands, which include coniferous tree species such as black pine (Pinus nigra), Scotch pine (P. sylvestris), and fir (Abies nordmanniana subsp. bornmuelleriana). In addition, coniferous species usually blend with oriental beech (Fagus orientalis) and oak species (Quercus sp.). Deciduous species, beech, and oak can be found in the pure form, and, though not very often, they form mixed stands with each other or other coniferous or deciduous trees, especially chestnut (Castanea sativa) and Alder (Alnus glutinosa).

The total population of the rural settlements and that of Yığılca, which is the largest settlement within the study area, are depicted in graphs in Figure 2, which are based on data collected from the censuses conducted between 1965 and 2010. A total of 18\% of the population lives in Yığılca town center, and the remaining 



Figure 1. Location of the study area
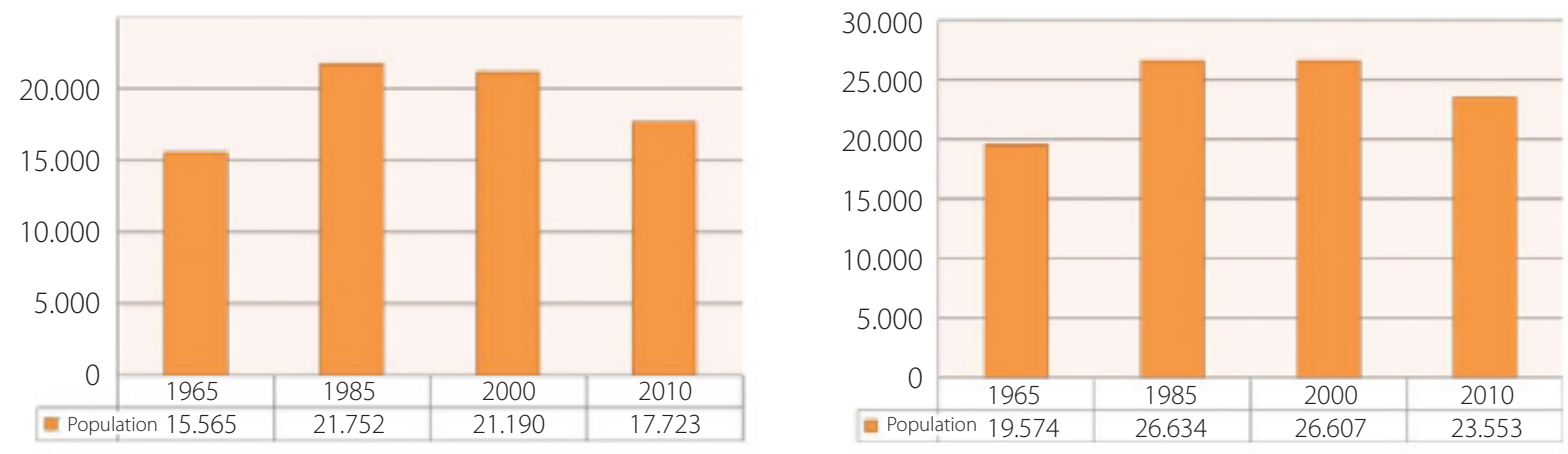

Figure 2. Temporal changes in population in Yığılca town center (left) and villages (right)

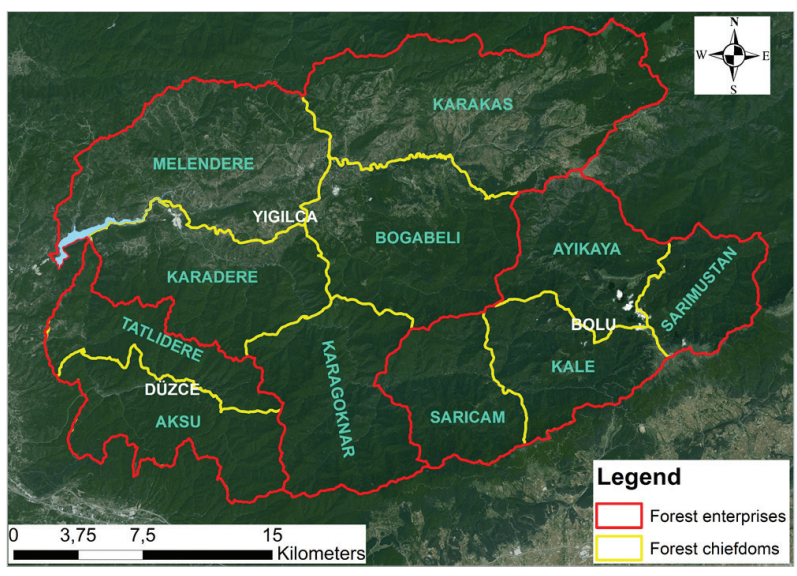

Figure 3. Forest enterprises and chiefdoms located within the study area

$82 \%$ lives in rural areas. It can be observed that the population has decreased steadily since 1985. The town loses its population to big cities due to inefficient terrain and the lack of industrialization (Anonymous, 2014). Some of the people living in the villages tend to move to the highlands to spend the hot summer months and engage in agricultural activities. In addition, seasonal workers arrive from the eastern provinces, especially for hazelnut harvest. Therefore, during the summer months, a temporary population density is observed on forest roads and in lands adjacent to the forests.
Within the study area, three forest enterprises (FEs) are located and 11 FC areas operate under these departments. The FCs include Ayıkaya, Kale, Sarıçam, and Sarımustan that are affiliated to Bolu FE; Tatlıdere and Aksu that are affiliated to Düzce FE; and Boğabeli, Melendere, Karadere, Karagöknar, and Karakaş that are affiliated to Yığılca FE. The entire area of these FCs, except Melendere, is included in the study area, while $91 \%$ of Melendere is within the study area. Figure 3 shows the FEs and FCs located within the study area.

The Yığılca FE constitutes the majority of the study area, and $65.2 \%$ of the overall area of Yığılca FE is composed of forested areas. About $97 \%$ of this forested area consists of productive forests. When the entire study area is taken into account, more than half (56.8\%) consists of forested area and the remaining $43.2 \%$ consists of deforested areas. Of the forested area, $97.1 \%$ is productive and the rest is degraded. Productive forests are usually mature in age and consist of thin or medium-sized sawtimber stands (Anonymous, 2015).

\section{Preparation and Analysis of Digital Data}

To examine the temporal changes in land use in the study area, first, 1/25,000-scale topographic maps and forest management plans of the study area that were prepared for the previous periods were obtained from Bolu Regional Directorate of Forestry using current management plans for the area. Stand maps of the year 1986 belonging to FCs within the study area were scanned at high resolutions and digitized using ArcGIS Desktop 


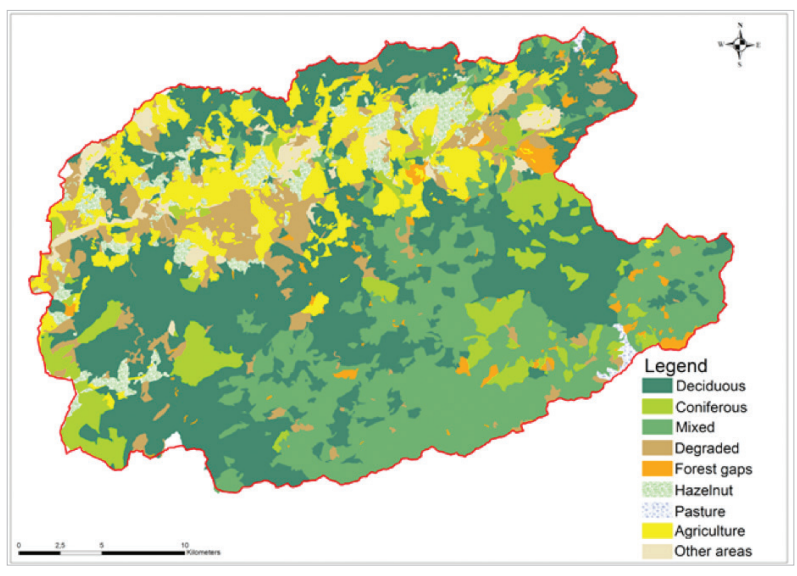

Figure 4. Distribution of land-use classes in 1986

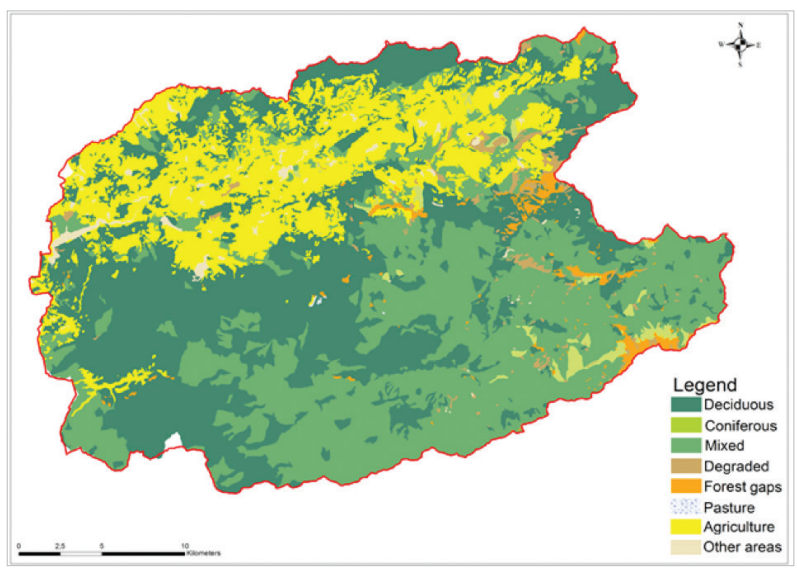

Figure 5. Distribution of land-use classes in 2010

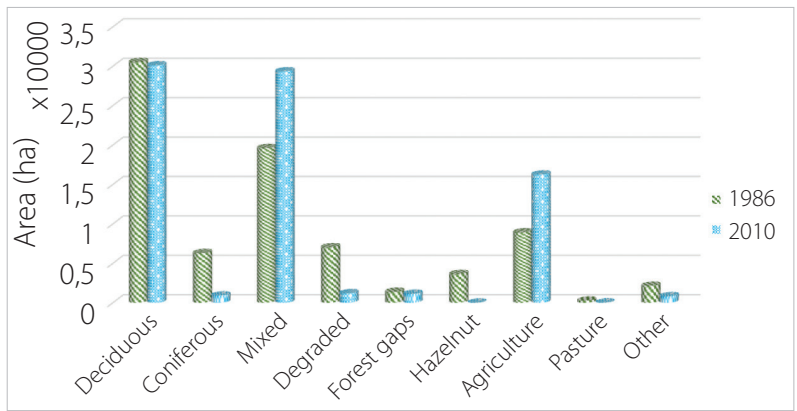

Figure 6. Areal distribution of land-use classes in 1986 and 2010

10.4 TM, a GIS software. The stand maps of 2010 were readily obtained in the digital form from the FEs and were analyzed for land classification. Aliases of stand types in the study were classified according to land-use types. In this manner, six classes, including forest, forest gaps, hazelnut, agriculture, pasture, and other fields, were categorized. Areas such as residential area, lake, depot, and mine were identified within other area classes. The forest areas were divided into groups of deciduous forests, coniferous forests, mixed forests, and degraded forests.
The mixed forest group was not divided into subgroups to avoid increasing the number of groups. The supplied country maps were digitized using GIS, and the boundary of the Hasanlar Dam basin, which constitutes the study area, was determined by obtaining the digital elevation model of the area. After digitizing the stand maps for the FCs in the study area, the attribute tables were also organized for each period. Databases created in the GIS were then transferred to Microsoft Excel, and the temporal changes in land-use patterns were evaluated.

\section{RESULTS AND DISCUSSION}

\section{Land-use Status of 1986}

Through the digitization of the 1986 stand maps, it was observed that $82 \%$ of the Hasanlar Dam basin is composed of forest areas. The percentiles of the types of forests in the forested areas are as follows: $38 \%$ of the area (30,520 ha) comprised deciduous forests, 25\% (19,621 ha) had mixed forests, 8\% (6,301 ha) was composed of coniferous forests, and 9\% (7,022 ha) of the area comprised degraded forests. Agriculture, hazelnut, pasture, and other areas made up a total of 18\% of the total area (Figure 4).

\section{Land-use Status of $\mathbf{2 0 1 0}$}

In 2010, it was observed that deciduous forest areas comprised the same proportion as that of the previous period (38\%; 30,118 ha), but there was a loss of 402 ha of area. The proportion of mixed forest areas increased by $12 \%$ (9,730 ha) compared to that of the previous period, which was a $37 \%$ increase of the total area $(28,945 \mathrm{ha})$. The proportion of coniferous forest areas decreased by $7 \%$ (5,384 ha) compared to that of the previous period at the rate of $1 \%$ (917 ha). Similarly, degraded forest area proportion decreased by $7 \%(5,827 \mathrm{ha})$ compared to that of the previous period at the rate of $2 \%(1,195 \mathrm{ha})$. With the decrease in the degraded forest areas and also considering hazelnut areas as agricultural areas, there was an increase of 9\% (6,495 ha) in the agricultural areas, suggesting a $20 \%$ increase in the agricultural areas of the total area (15,420 ha). In addition, there were small decreases in other land-use classes (Figure 5).

The changes in land-use patterns in 11 FCs located in the Hasanlar Dam basin during this 24-year period are depicted in Figures 6 and 7.

\section{Land-use Changes between 1986 and 2010}

Land-use changes during the years 1986-2010 are presented in Table 1 and Figure 8. It can be observed that there was a huge transition from deciduous forests to mixed forests, and 2,660 ha of deciduous forests was converted into agricultural areas. Although there was a transition from deciduous forest land to other landuse classes, this transition was not in very large proportions. Regarding the changes that occurred in the coniferous forest areas, it there was a large decrease in this period and more than half of the coniferous forest areas turned into mixed forest areas. Moreover, there were transitions from coniferous forest areas to deciduous forest areas. The mixed forest areas also showed more than a 50\% increase in this period, which amounted to 29,351 ha from 19,621 ha. Along with this increase in mixed forest areas, there 

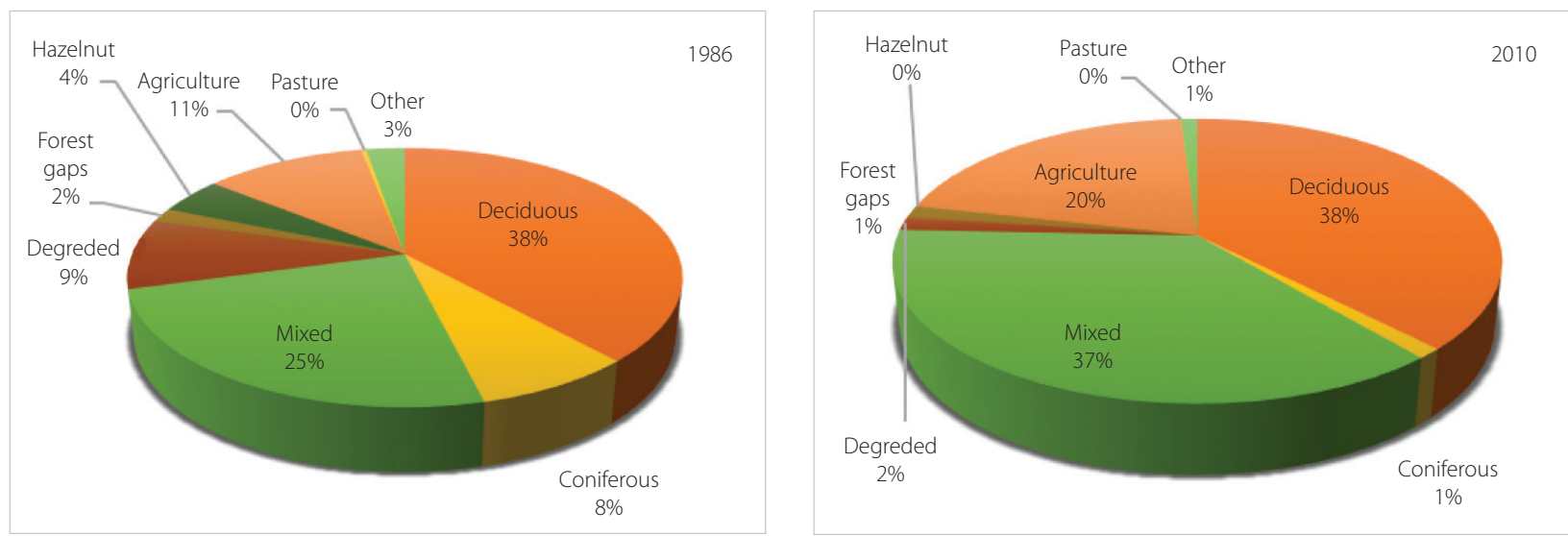

Figure 7. Distribution of land-use classes as percentages in 1986 and 2010

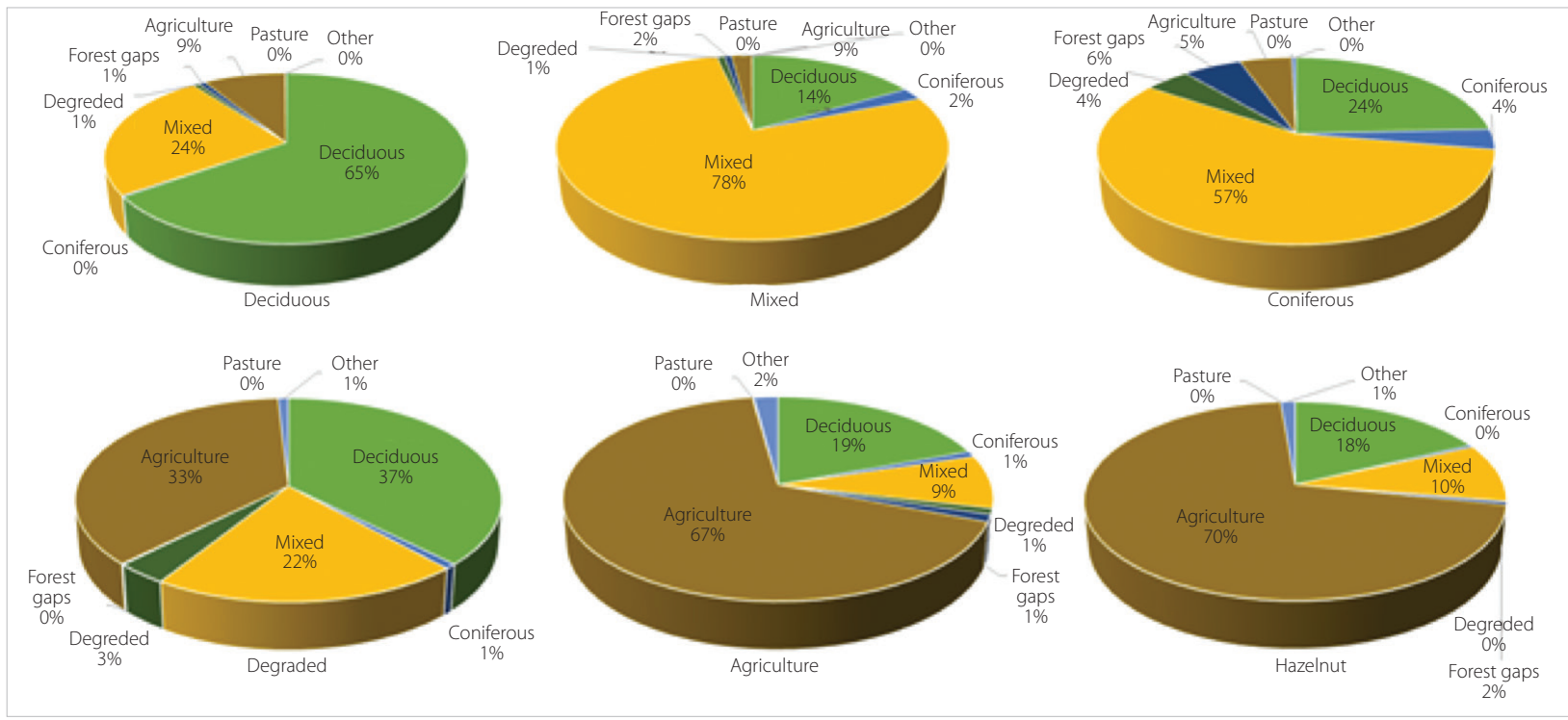

Figure 8. Proportional changes and transitions in land use between 1986 and 2010

Table 1. Land-use changes and transitions between 1986 and 2010

\begin{tabular}{|c|c|c|c|c|c|c|c|c|c|c|}
\hline & \multicolumn{10}{|c|}{ Land use in 2010 (ha) } \\
\hline & $\begin{array}{l}\text { Land-Use } \\
\text { Status }\end{array}$ & $\begin{array}{l}\text { Decidu- } \\
\text { ous }\end{array}$ & $\begin{array}{c}\text { Conifer- } \\
\text { ous }\end{array}$ & Mixed & $\begin{array}{l}\text { Degra- } \\
\text { ded }\end{array}$ & $\begin{array}{l}\text { Forest } \\
\text { Gaps }\end{array}$ & $\begin{array}{l}\text { Agricul- } \\
\text { ture }\end{array}$ & Pasture & Other & TOTAL \\
\hline \multirow{10}{*}{ 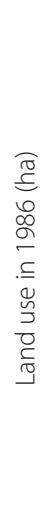 } & Deciduous & 19859,1 & 61,4 & 7482,7 & 194,3 & 234,7 & 2660,4 & 0,0 & 27,5 & 30520,2 \\
\hline & Coniferous & 1526,5 & 220,2 & 3578,6 & 274,3 & 357,9 & 318,3 & 0,0 & 25,8 & 6301,6 \\
\hline & Mixed & 3262,0 & 426,5 & 15242,0 & 147,3 & 138,9 & 392,8 & 1,7 & 10,0 & 19621,1 \\
\hline & Degraded & 2632,7 & 54,9 & 1453,2 & 244,4 & 10,8 & 2562,9 & 0,0 & 63,7 & 7022,6 \\
\hline & Forest Gaps & 368,3 & 41,5 & 329,4 & 199,8 & 121,4 & 306,7 & 5,6 & 4,7 & 1377,4 \\
\hline & Hazelnut & 648,1 & 13,8 & 344,0 & 4,2 & 18,7 & 2559,2 & 0,0 & 47,7 & 3635,7 \\
\hline & Agriculture & 1730,3 & 78,9 & 749,2 & 85,0 & 103,6 & 5981,2 & 11,1 & 186,0 & 8925,4 \\
\hline & Pasture & 5,6 & 16,0 & 83,6 & 19,8 & 141,8 & 0,0 & 0,3 & 0,0 & 267,1 \\
\hline & Other & 85,2 & 4,2 & 88,7 & 25,9 & 0,0 & 638,7 & 0,0 & 460,0 & 1302,6 \\
\hline & TOTAL & 30117,8 & 917,4 & 29351,4 & 1195,0 & 1127,9 & 15420,1 & 18,7 & 825,3 & 78973,6 \\
\hline
\end{tabular}


Table 2. Change in land use over the years (ha)

\begin{tabular}{|lcccccc|}
\hline Year & Forest & Hazelnut & Agriculture & Pasture & Other & Total (ha) \\
1986 & 64843 & 3635 & 8925 & 267 & 1303 & 78973 \\
2010 & 62709 & 0 & 15420 & 19 & 825 & 78973 \\
\hline
\end{tabular}
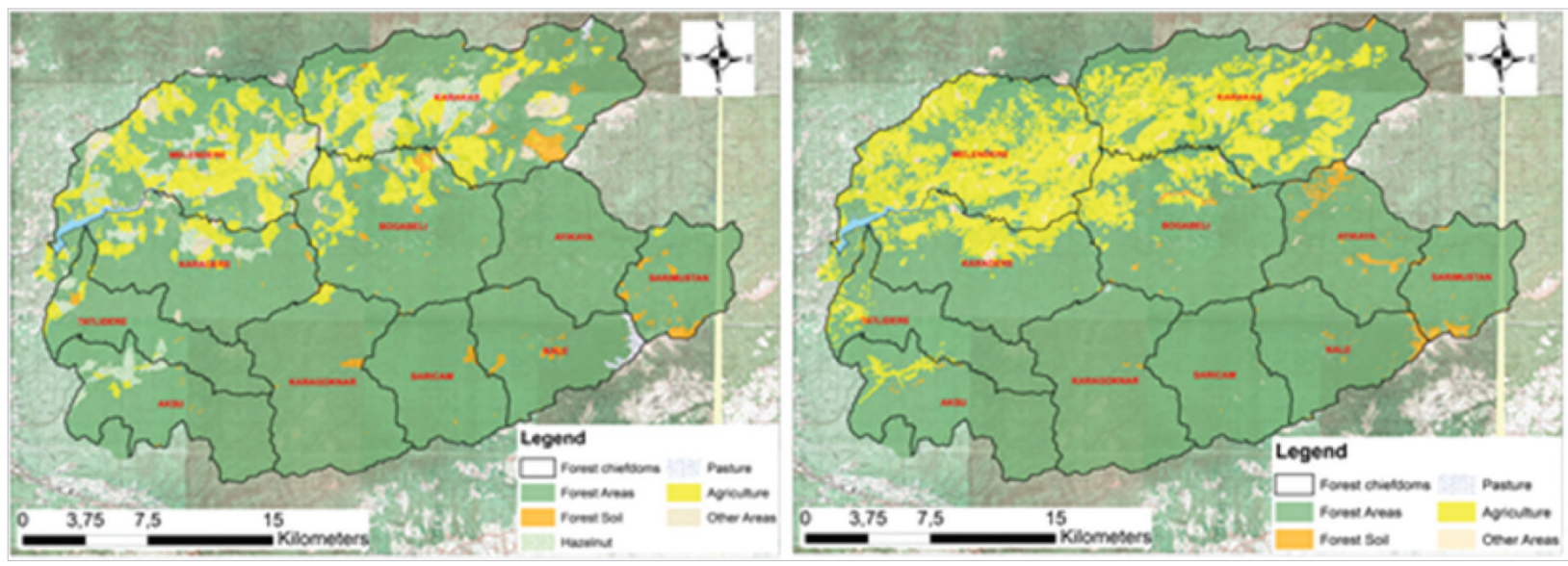

Figure 9. The spatial status of land-use patterns in 1986 (left) and 2010 (right).

were transitions to other land-use types as well. The transition to the mixed stands was primarily from the deciduous and coniferous forest areas, whereas the mixed forest areas were primarily converted into deciduous forest areas.

There was a significant decrease in the degraded forest areas during 1986-2010. Although this decline was effective for the rehabilitation of degraded forests into productive deciduous forests, transformation of the degraded forest areas into agricultural areas due to the crimes of the local people, such as for occupation, illegal cutting, and clearing, is also noticed as another reason for the decrease in the degraded forest areas. There was no significant change in the land-use status of forest gaps. Although the agricultural areas were converted into deciduous forest areas, considering the hazelnut areas as agricultural areas in the 2010 forest management plan stand maps was especially the primary reason for the increase in agricultural areas.

During the period under study, it can be observed that the forest areas (deciduous, coniferous, mixed, and degraded forests) decreased by about 2,130 ha between 1986 and 2010, from its initial level of 64,843 to 62,709 ha. This decrease was primarily due to the increase in the agricultural areas in the forest areas. There was a $42 \%$ increase in agricultural areas between these two periods (Table 2).

The general land-use statuses of 1986 and 2010 are depicted in Figure 9. All the subgroups, without dividing the forested areas, were evaluated under the forest major group to visually assess the primary changes.

The forest management discipline attempts to ensure that forest areas are regulated in line with the demands of the com- munity through forest management plans and monitors the changes in these resources over the periods according to the inventory it has compiled. Land-use patterns are determined by the forest management teams through 10- or 20-year plans. The work of these teams is of vital importance in preparing stand maps. Due to these reasons, it is very important for the people in forest management teams to have the knowledge and experience for comprehending land-use patterns and the ability to anticipate future outcomes of the decisions they make in the determination of land-use patterns and follow-up changes.

A decrease of about 3\% (2,133 ha) occurred in the forest areas during the period 1986-2010 (Table 2). When deciduous forests are evaluated, in general, although there was a small spatial decrease in the period between 1986 and 2010, there was no proportional change between these two periods. There were transitions from deciduous forests to other land-use types and from other land-use types to deciduous forest areas. A total of $65 \%$ of the deciduous forests was preserved as spatial distribution in the process from 1986 up to the year 2010. During this period, coniferous forests lost their dominance and were transitioned to deciduous and mixed forest cover types. The largest change in area and proportion of land use was observed in the mixed forest areas. The proportion of mixed stands with an area of $25 \%$ (19,621 ha) in 1986 increased to $37 \%$ (29,351 ha) during the period up to the year 2010, especially in the deciduous and coniferous forest areas, through the transformation of their mixed status with natural processes and management interventions, turning into mixed forest status, and with the rehabilitation or reforestation of degraded forests. In their studies at Duzce-Cumayeri region on land-use changes during the period 1987-2010, Sivrikaya et al. (2011) observed similar increases in 
deciduous and mixed forest areas as those achieved in the present study, along with a decrease in coniferous and degraded forest areas. The findings of the increase in the deciduous and mixed forest areas due to the transitions from coniferous forest areas are effective. The reforestation operations in the degraded forests using the deciduous species and, especially, the result of the transition to deciduous forests are similar to those of the present study.

Although there was no significant difference in population between the 1985 census $(26,634)$ and the 2000 census $(26,607)$ in the villages within the study area, there was a decrease of approximately 13\% between 2000 and 2010 (23,553). Several studies (Gümüş et al. 1996; Ateşoğlu and Tunay 2010; Özsan 2011; Bayar 2003) have indicated that population growth has a negative impact on forest areas and natural resources and that these areas are declining. However, in the study of Kadıoğulları and Başkent (2007) on the spatial and temporal dynamics of Gümüşhane during the years 1970-2000 and in the study of Günlü et al. (2008) on land-use changes in Rize between 1970 and 2000, the authors concluded that there was a decrease in both the population and forest areas. In the present study, it was observed that despite the decrease in the population between 2000 and 2010, there was no increase in the forest areas, but a decrease in forest areas was observed during this period. This situation indicates that other factors may also influence land-use changes. That is why it can be observed that the increase in the pressure in the forest areas is not always directly proportional to the increase in population. This is because, besides forestry operations, biotic and abiotic damages can also cause a change in forestlands. Thus, there may be changes in the structural elements of the stands (such as species mixture or standing stock), although there is not always a land-use change that leads to deforestation. In addition, it is observed that previous forest destruction activities maintain the current state, and the forest continues to be used for activities such as grazing and agriculture. It has been observed that some activities generally protect the forests, such as raising the awareness of the people, attaching more importance to the protection of forests by enacting laws, successful forestation, and the formation of income-generating resources, which have now come to the forefront.

The hazelnut areas in the stand maps of 1986 were not included in the stand maps of 2010. This was due to the fact that the hazelnut areas were not included in the distribution charts for land-use types in the Statement on Procedures and Principles Regarding the Preparation of Ecosystem-based Functional Forest Management Plans (OGM 2014). This is why the inclusion of the entire land-use pattern of hazelnut areas into agricultural areas in the management plans resulted in considering hazelnut areas as being transformed. This is primarily due to the fact that the hazelnut areas were not removed from the ground, but only the land-use patterns were changed for agriculture. In the period of analysis, some of the hazelnut areas were transformed into forest areas and most of them (2,559.2 ha) were considered as agricultural areas with only a change of name.
Regarding the agricultural areas, there was a $42 \%$ increase from 1986 until the year 2010. Considering the land-use patterns of hazelnut areas as agricultural areas in 2010 was particularly responsible for this increase. In addition, there were transitions to agricultural areas, especially from the deciduous (2,660.4 ha) and degraded forests (2,562.9 ha). Sivrikaya et al. (2011) determined a 5\% increase in agricultural land between 1987 and 2008 in their study on land-use changes in the Düzce-Cumayeri region. They concluded that the major cause for the increase in agricultural area in that region was the consideration of the fields indicated by hazelnut aliases in the agriculture plans as agricultural areas. Gülersoy (2013) found that agricultural land had increased by $71 \%$ between 1987 and 2011, despite a 62\% reduction in rural population, and stated that this stemmed from the conversion of pastures and bottom lands into agricultural areas. The reason for this observation is expressed as an increase in food demand and the exploitation via agriculture. In the study conducted by Doygun (2012), agricultural areas were reported to decrease by $58 \%$, for which the author stated that the agricultural lands were converted into forest areas due to the successful forestation activities.

Although there were minor changes in other land-use classes, there was a decrease and transition to agricultural areas. In other areas, residential areas occupied a large amount of space, and it could be understood that the transitions were primarily caused due to the changes in these areas. This situation is believed to be caused not by the physical change in the area but by the representation of the stand type alias in the stand type maps. In this case, it was effective to change some of the aliases that were shown as Z-Is in the previous period and that showed the cases where both the agricultural and the residential areas were intertwined to indicate only the agricultural areas in the new period. On the other hand, the designation of the residential areas as smaller polygons in the new period, which had been drawn as larger polygons in the previous period, including the surrounding agricultural areas, led to a decrease in the amount of other areas.

\section{CONCLUSION}

Due to the scope of the study, while the maps were digitized in terms of land-use forms, cadastre and ownership conditions were not considered, and only the status of the land reflected on the stand maps was analyzed. For example, a place that was transformed into an agricultural field was still considered as an agricultural area even though it was still in the forest status. Therefore, the effects of possible sources of error that may occur during the preparation of the stand maps were ignored and the stand maps were analyzed assuming the maps to be accurate. Various errors can occur in the preparation of stand maps using a combined inventory during the interpretation of aerial photographs, satellite images, and terrestrial measurements, which are based on temporary sample plots. Some forest stands that were missed in the previous inventory period may have been reflected in the map in the subsequent period, and some areas that were merged under the same type may have later been expressed as a separate type. 
In such studies using GIS, it is necessary to acquire a large number of control points while transforming old stand type maps into actual coordinates. Otherwise, even if the outer boundaries of the maps to be compared overlap, the glitches within the boundaries of the inner polygon that depict the stand boundaries may not be removed. This may lead to the perception that the periodically unchanged areas have been converted into different forms of land use when the overlay analysis is carried out. If this situation is not taken into consideration, the analysis will not be very healthy.

Based on the results of the present study, in addition to the transitions within the forest areas, in the period between 1986 and 2010, the forest areas decreased by about 3\% (2,134 ha) and there were large-scale transformations into agricultural areas. Through the Melen project, water is being transported from the Hasanlar Dam to İstanbul. Since changes in land use can affect the quantity and quality of water supplied from the dam basin, it is necessary to keep these changes under control. Illegal land use should be prevented, cadastral work should be completed, and forest boundaries should be determined. Although the population in the study region has been gradually decreasing during the period of analysis, the agricultural areas have increased. There is a need for activities to reduce the pressure on the forests by increasing the income level of the people living in this region.

\section{REFERENCES}

- $\quad$ Anonymous, http: //www.duzcenufus.gov.tr/index.php?option = com (Accessed on: November 20, 2014).

- Anonymous http: //boluobm.ogm.gov.tr/sayfalar/ormanıletmemudurlukleri.aspx (Access 07 December 2015).

- Ateşoğlu, A., Tunay M., 2010. Spatial and temporal analysis of forest cover changes in the Bartin region of northwestern Turkey. African Journal of Biotechnology 9(35): 5676-5685.

- Bayar, R., 2003. Land Use-Population Relationship-Anamur example. Journal of Geographical Sciences 1 (1): 97-116.

- Bussink, C.B., Hijmans, R.J., 2000. Land-use change in the Cajamarca catchment, Peru, 1975-1996. http://cipotato.org/site/inrm/home/ publicat/01cpb009.pdf. (Accessed: 15 March 2017).

- Değermenci, A.S., Zengin, H., 2016. Investigation of spatial and temporal change of carbon accumulation in forests: An example of Daday planning unit. Artvin Çoruh University Journal of Forestry 17(2): 177-187.

- $\quad$ Doygun, H., Oğuz, H., Kesgin Atak, B., Nurlu, E., 2012. Remote Sensing and Investigation of the Effects of Field Use Variations on Natural Characteristic Coastal Areas with the Help of GIS: Çiğli / İzmir Example, KSÜ, Journal of Engineering Faculty, Special Issue, 1.

- $\quad$ Erol, A., 2007. Land Use and Basin Approach in Turkey. Süleyman Demirel University, Journal of Agriculture Faculty 2(1): 21-25.

- European Environment Agency. Land use in (http://www.eea.europa.eu/tr/themes/landuse/about-land-use), (Accessed: 19 November 2016).
- Gülersoy, A. E., 2013. Temporal Change of Land Use in Çorum Central District (1987-2011) and Environmental Impacts. Journal of Geography 11(2): 169-194.

- Gülersoy, A.E., 2014. Temporal Change of Land Use in Seferihisar and Suggestions for Ideal Land Use. SDU Faculty of Arts and Sciences Journal of Social Sciences 31: 155-180.

- Gümüş, C., 1996. Causes of Forest Crimes in the Amasya Regional Directorate of Forestry. Kafkas University Journal of Artvin Forestry Faculty 1(2): 41-51.

- $\quad$ Günlü, A., Kadıŏulları, A., I, Keleş, S., Başkent, E., Z., 2008. Spatiotemporal changes of landscape pattern in response to deforestation in Northeastern Turkey: a case study in Rize. Environmental Monitoring and Assessment 148: 127-137. [CrossRef]

- Kadıogulları, A. I.., Başkent E., Z., 2007. Spatial and temporal dynamics of land use pattern in Eastern Turkey: a case study in Gümüşhane. Environmental Monitoring and Assessment 138: 289303. [CrossRef]

- Kadıŏulları A I. Karahalil U., 2013. Spatiotemporal Change of Carbon Storage in Forest Biomass: A case Study in Köprülü Canyon National Park, University of Kastamonu. Journal of Forestry Faculty 13(1): 1-14.

- OGM. 2014. Procedures and Principles Regarding the Preparation of Ecosystem-Based Functional Forest Management Plans, Statement No: 299. Publication of Presidency of Forestry Administration and Planning Department.

- $\quad$ OGM. 2015. Turkish Forest Presence 2015. T.C. Ministry of Forestry and Water Affairs General Directorate of Forestry.

- OGM. 2006. http://www.ogm.gov.tr/ekutuphane/surdurulebilirormanyonetimi/dok/soy/kriter/göstergeleri.pdf (Accessed: 15 November 2013).

- Özçağlar, A., Özgür, M., Somuncu, M., Bayar, R., Yılmaz, M., Yüceşahin, M, Yavan, N, Akpınar, N., Karadeniz, N., 2006. Land Use Decisions Developed Due to Natural and Human Resource Evaluation in Çamlıhemşin District. Geographical Sciences Journal 4(1): 1-27.

- $\quad$ Özsan, M., 2011. Rural Development Research in the Forest Villages Beypazarı. MSc Thesis, Kahramanmaras Sutcu Imam University, Institute of Science and Technology.

- $\quad$ Özşahin, E., Atasoy, A., 2014. Effect of Land Use and Land Cover Change (1990-2011) on Erosion in Lower Asi River Basin (Hatay). International Journal of Social Researches 7(31): 457-468.

- Rounsevell, M., Evert, F., Reginster, l., Leemans, R., Carter, T.R., 2005. Future scenarios of European agricultural land use II. Projecting changes in cropland and grassland. Agriculture, Ecosystems and Environment 107: 117-135. [CrossRef]

- Sivrikaya, F., Çakır, G., Akay, A. E., 2011. Factors of land use/cover change: A case study from Turkey. Academic Journals Scientific Research and Essays 6(17): 3684-3696. [CrossRef]

- Somuncu, M., Akpınar, N., Kurum, E., Çabuk Kaya, N., Özelçi Eceral, T., 2010. Evaluation of Land Use Function Change in Gümüşhane Plateaus: An Example of Kazıkbeli and Alistire Plateaus, Ankara University. Journal of Environmental Sciences 2(2): 107-127.

- Wu R. ve Tiessen H., 2002. Effect of Land Use on Soil Degradation in Alpine Grassland Soil, China. Soil Science Society of America Journal 66(2002):1648-1655. [CrossRef] 